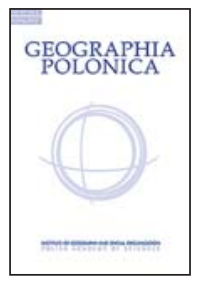

\title{
EVOLUTION OF THE HYDROLOGICAL REGIME IN RELATION TO CLIMATE CHANGE: CASE OF THE BOUREGREG RIVER BASIN, MOROCCO
}

\section{Rajae El Aoula ${ }^{1}$ (iD $\cdot$ Gil Mahe ${ }^{2}$ (D) Nadia Mhammdi ${ }^{1}$ (D) Abdellatif Ez- zahouani $^{3}$ - llias Kacimi ${ }^{3}$ (D) Kenza Khomsi ${ }^{4}$ (D)}

${ }^{1}$ Research Center of GEOPAC, Geophysics and Natural Hazards Laboratory

University of Mohammed V in Rabat, Scientific Institute Morocco

Rabat: Morocco

e-mails: elaoula.rajae@gmail.com (corresponding author) • nmhammdif@yahoo.com

${ }^{2}$ UMR HydroSciences Montpellier

IRD: France

e-mails: gilmahe@hotmail.com・iliasKacimi@yahoo.fr

${ }^{3}$ Water Center, Natural Resources, Environment and Sustainable Development Laboratory of Geoscience, Water and Environment

University of Mohammed V in Rabat

Rabat: Morocco

e-mail: gmezzahouani@gmail.com

${ }^{4}$ National Directorate of Meteorology

Casablanca: Morocco

e-mail: K.Khomsi@gmail.com

\begin{abstract}
The objective of this study is to investigate the evolution of rainfall and flow in the Bouregreg watershed, and to identify the most vulnerable regions to climate change over a period of 36 years from 1977 to 2013. Results show significant variations between these sub-regions in term of monthly flows and monthly regimes. January and February rainfall amounts are the most affected by the reduction of rainfall since the drought started end of the 1970's, inducing a reduction of flows at all hydrological stations mainly since 1979 . The year 1996 shows very high precipitations over all sub-basins, and also separates two periods with different rainfall time series variations according to two regions over the basin: the region of the Tsalat sub-basin in the Southeast wet and mountainous area (Middle Atlas) shows a durable decrease of rainfall compared to the Ain Loudah sub-basin in the Center-West semi-arid plateau area.
\end{abstract}

\section{Key words}

climate change $\cdot$ rainfall $\cdot$ standardized index $\cdot$ rupture $\cdot$ watershed $\bullet$ Bouregreg Morocco 


\section{Introduction}

Rainfall is the most important climatic factor to both ecosystems and people. Thus, the detection of trends and variations in long hydroclimatological series is relevant for climate change mitigation and adaptation strategies. Particularly, Nord African countries suffered economically, socially and ecologically from drought during the last decades as in Morocco during years from 1980 to 1985 and from 1991 to 1995 (Tsiourtis, 2001; Singla et al., 2010; Khomsi et al., 2016; Zamrane et al., 2016a, 2016b), in Algeria (Taibi et al., 2017, 2019; Hadour et al., 2020; Hallouz et al., 2020 and in Tunisia (Bargaoui et al., 2014; Kotti et al., 2016; Tramblay et al., 2019). Natural systems and human activities are most at risk due to lack of regular water supply during the year. This is due to the high inter-annual variability and the significant seasonality of rainfall. This study was developed from the results of the SIGMED project (Mahé et al., 2013). This basin represents one of the five major Moroccan rivers by its flow and size and it has the distinction of being limited to $18 \mathrm{~km}$ from its mouth by a dam (Sidi Mohamed Ben Abdellah, SMBA) of a volume exceeding $1 \mathrm{Md} \mathrm{m}^{3}$. Hydroclimatic regime of the basin is influenced both by NAO (North Atlantic Oscillation) and $\mathrm{MO}$ (Mediterranean Oscillation) (Khomsi et al., 2016; Zamrane et al., 2016a). This has an impact on the evolution of hot episodes in Morocco's internal areas (Khomsi et al, 2013). Moreover, in a semi-arid Mediterranean context, the decrease of rainfall since 1979 and the increase in extreme events, have modified the conditions for erosion and solid transport in this basin (Driouech et al., 2010a; Singla et al., 2010; Khomsi et al., 2012, 2016), as it has been reported by Hallouz et al. (2018) in Algeria. It is therefore important to study

1 The SIGMED project stands for "spatial approach of the impact of agricultural activities in the Maghreb on sediment transport and water resources in large river basins" retrieved from http://armspark.msem. univ- montp2.fr/sigmed/. the evolution of water resources available in a changing climate environment. Previous studies (Knippertz et al., 2003; Driouech et al., 2009; Sinan et al., 2009; Driouech et al., 2010b; Sebbar et al., 2011; Tramblay et al., 2012; Zhriri et al., 2017; Rivoire et al., 2019) in Morocco's watershed used statistical and modeling techniques to analyze the nature and extent of trends in time series. However, several gaps still exist in current knowledge and understanding of the annual variability of regional climates and river systems in the Bouregreg and other Moroccan watersheds. This study completes the previous ones about the Bouregreg by including the study of several sub-basins of the Bouregreg, allowing a better description of local variations, including the continental/coastal effect. This will reveal regional impact on varying local conditions and implications on hydrological regime in this important watershed, where many agricultural activities have been developed, and where most river runoff is stored in a large dam for portable water consumption for the most heavily populated basin in the country (with about 8 million people between Casablanca, Kenitra, and Rabat). This study investigates, trends in the rainfall and hydrometric series, and evolution of rainfall and flow from a regional scale over 36 years, using monthly and annual observations. The objectives of this work are to identify the main factors of climate variability through the detection of similarities and differences between the responses of measurement stations, and consider the contribution of each region to the development of sustainable water management in Bouregreg watershed in the context of climate change. The stations used in this work are located in the upstream half of the basin, and are not influenced by the dam. They present an interesting dataset to test the impact of climate change on the hydrological regime, and thus to the variability of the water resource that would be available for the downstream development of these stations, according to a method used in Morocco by Singla et al. (2010). 


\section{Study area}

The Bouregreg watershed (Fig. 1) is located in the Mediterranean area at latitude $32^{\circ} 50$ to $34^{\circ} 30 \mathrm{~N}$ and extends from longitude $5^{\circ}$ to $7^{\circ} \mathrm{W}$ (Beaudet, 1969). The hydrographic network develops around two main rivers, the Bouregreg and the Grou rivers, which respectively drain an area of $4000 \mathrm{~km}^{2}$ and $3600 \mathrm{~km}^{2}$ (Lahlou, 1986), and a smaller basin coming from the South, the Korifla, divided into two tributaries. The water supplies of the basin are closely related to rainfall. The average water potential of the Bouregreg basin is estimated at $680 \mathrm{~mm}$ per year (Ministry of Energy, Mines, Water and the Environment).

The hydrographic network of the Bouregreg watershed is fairly developed. It consists of two main rivers, namely:

- Bouregreg river, which drains an area of $3830 \mathrm{~km}^{2}$, corresponding to the northeast part of the basin.

- Grou river and its tributaries, Korifla and Akrech which drain the southwest part. It has a total area of $5760 \mathrm{~km}^{2}$.
The Bouregreg river is located at 5.4 and $-6.8^{\circ} \mathrm{W}$ and 32.8 to $-34^{\circ} \mathrm{N}$, representing the northeastern part of the Bouregreg basin It originates from the Middle Atlas mountains at altitude $1627 \mathrm{~m}$ in Jebel Mtourzgane and Grou (Beaudet, 1969), and 50\% of the area is located at altitudes between 500 and $1000 \mathrm{~m}$ (SIGMED project; Mahe et al., 2013). The basin consists of a combination of monotonous plateaus, deep gorges and basins partitioned by steep ridges over an area of $9656 \mathrm{~km}^{2}$ (Marghich, 2004) on the western humid side of the country. The Bouregreg stream follows a straight overall direction SE-NW and extends over a length of $240 \mathrm{~km}$. The last 23 kilometers of the lower course of the Bouregreg end with a partially developed estuary (Lahlou, 1986). The climate is sub-humid to semiarid (Mahé et al., 2012) and average annual rainfall ranges from about $400 \mathrm{~mm}$ in coastal regions to $760 \mathrm{~mm}$ in the western part of the basin (Fig. 2). The number of rainy days per year is 75-100 in mountainous regions and 60-75 elsewhere (Khomsi, 2014).

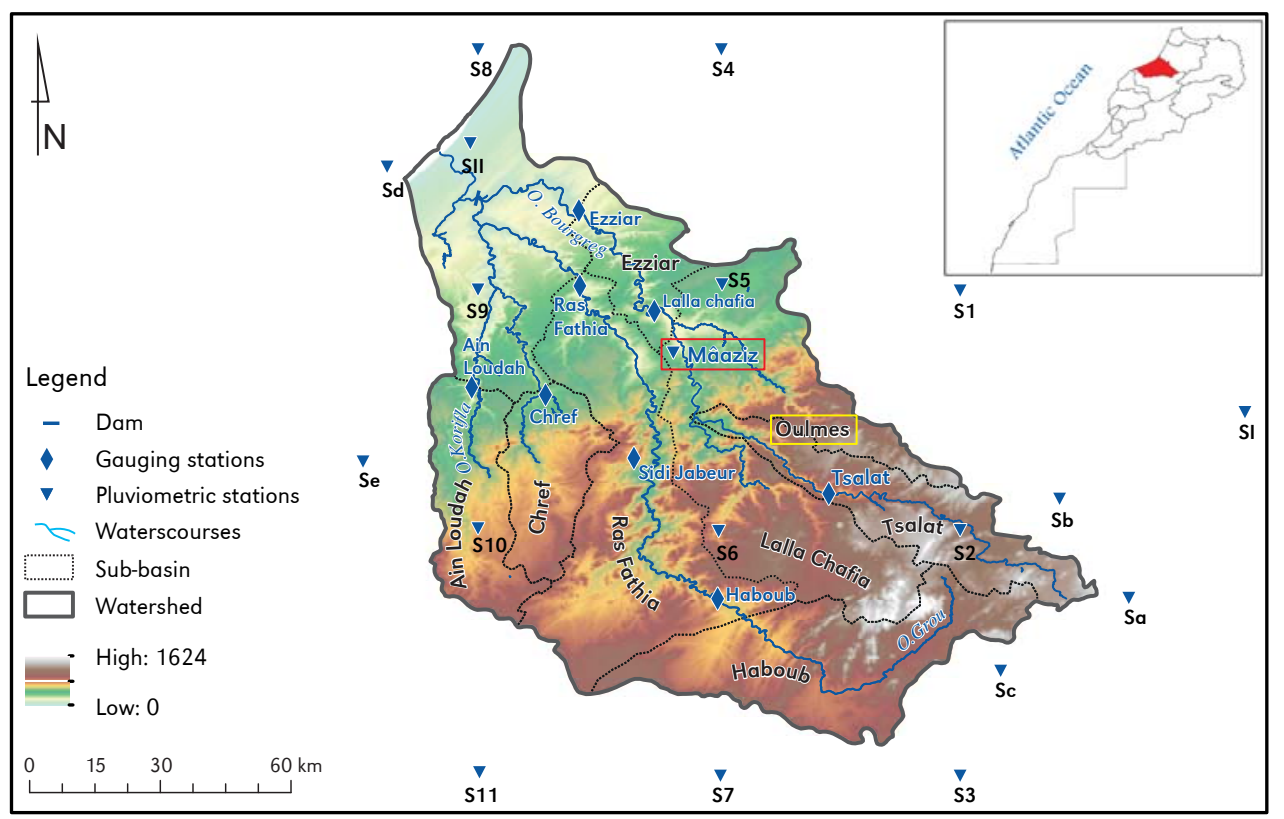

Figure 1. The Bouregreg catchment and the main sub-basins 

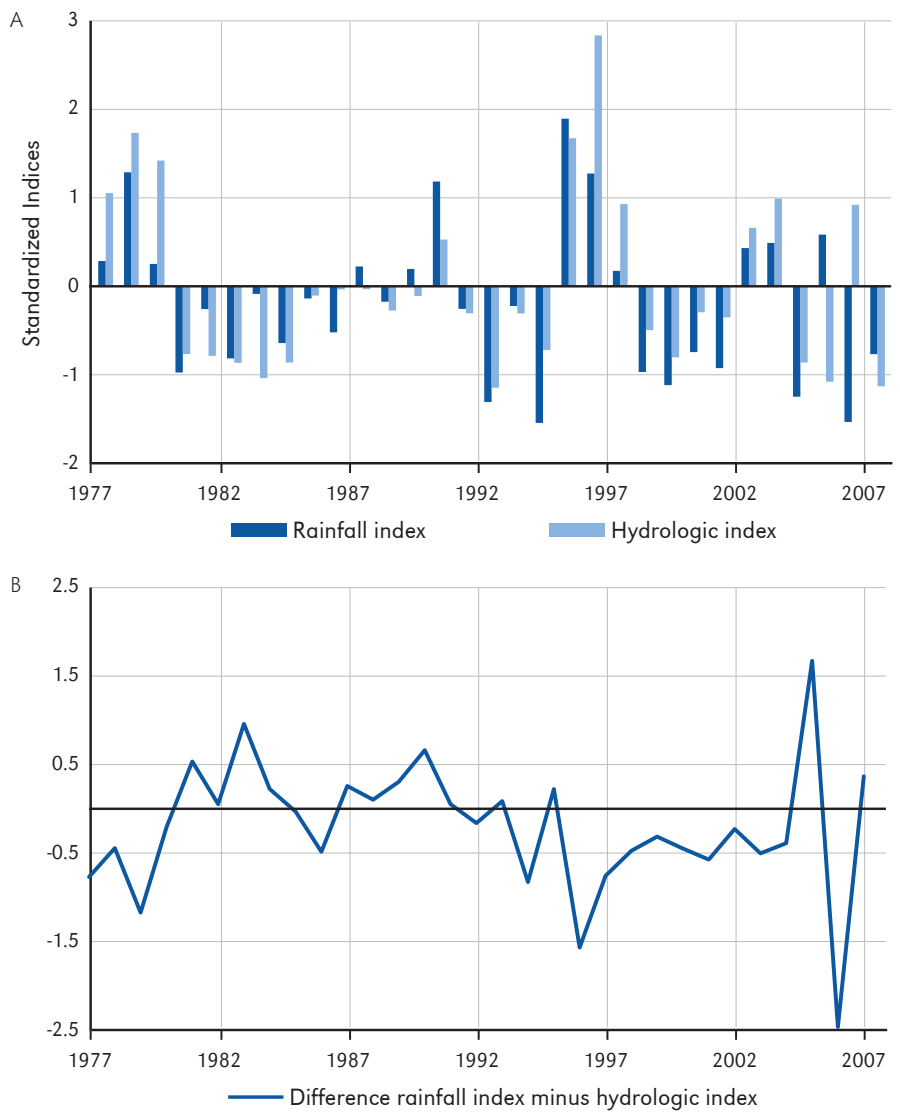

Figure 2. Rainfall and hydrologic indexes from 1977 to 2007 for the Bouregreg catchment $\left(9970 \mathrm{~km}^{2}\right)$

\section{Data and methods}

\section{Source of data}

Rainfall data used in this study come from 18 stations available on the SIEREM database of the Environmental information system for water resources (Boyer et al., 2006; Dieulin et al., 2006; Dieulin et al., 2019), and recent data from 8 stations of Bouregreg and Chaouia hydraulic agency for the period 1977-2013. The SIEREM rainfall database totalizes more than 10,000 stations over the whole African continent (Rouche et al., 2010), starting before the 20th century for the oldest ones. They originate from several sources: the former rainfall database shared by all western African countries within ASECNA (African agency for the security of aerial navigation), the databases of the FRIEND-Water program from UNESCO, and data shared by IRD and their national partners during research project. These data have been crossed and improved according to the CRU raw database, implementing some areas with less data in each base. The most recent data mainly during the 80 s were obtained from the GPCC (Global Precipitation Climatology Centre), and national services. The raw data were strictly analyzed following many statistical tests, and about 6000 stations were eventually used for the interpolation of station data to obtain monthly gridded data sets from January 1940 to December 1999 , at the $0.5^{\circ}$ square scale. Dieulin et al. (2019) indicated different techniques used and the validation with observed data, and present a comparison 
with the CRU data on the same area and period, which show that SIEREM gridded data better represent rainfall in many areas of Africa than the CRU especially in North Africa.

The flow data were collected from 8 flow measurement stations by the Bouregreg and Chaouia hydraulic agency (ABHBC) and cover a period from 1977 to 2007. The quality of the flow data used in this work is ensured by the $\mathrm{ABHBC}$, which operates continuous discharges automatic measurements, and regular gaugings at all stations to ensure an up to date rating curve. The following methods are used in this study.

\section{Rainfall and hydrometric indices}

Rainfall and hydrometric indices are used to characterize the temporal heterogeneity of climatological variability and to identify major trends in hydroclimatological series. To visualize the annual deficit and surplus periods, these indices were centered and reduced using the following formula:

$$
V_{c r}=\left(P-P_{\text {moy }}\right) / \sigma
$$

where:

$\mathrm{V}_{\mathrm{cr}}$ - is the Reduced Centered Variable (Rainfall Index (SPI) or Hydrometric Index (SDI) according to the variable under study),

$P \quad$ - is the cumulative of the variable over a given period $t$,

$\mathrm{P}_{\text {moy }}$ - is the mean of the time series over the period of time, and

$\sigma \quad$ - is the standard deviation of the series over the period (Hallouz et al., 2013).

\section{Thiessen Polygon}

Precipitation measured at a meteorological station represents rainfall falling at a particular geographical point and not a spatial rainfall. Thiessen polygon method assigns to each rain gauge a zone of influence whose area, expressed as a percentage, represents the weighting factor of the local value. The different zones of influence are determined by geometric cutting of the basin on a topographic map. The weighted mean precipitation for the basin is then computed by taken the sum of the rainfall of each station, multiplied by their weighting factor, divided by the total area of the basin (Mahé et al., 1994).

\section{Statistical methods for rupture detection}

Statistical tests are used to detect a trend or an average break in the series. The tests are grouped together in the Khronostat software (1998) produced by the IRD and available on the HydroSciences Montpellier website (http://www.hydrosciences.org).

Pettitt test (Pettitt, 1979) was used on all selected positions to identify an average "break" in the annual and monthly rainfall and hydrometric series. This test, despite its robustness, is non-parametric and derives from the formulation of the Mann-Whitney test. The absence of a rupture in the time series $X$ constitutes the null hypothesis $H_{0}$.

Bayesian method of Lee and Heghinian (1977) allows to determine the date and the amplitude of the rupture. This method provides the probability that a change occurs at a time $t$ in a time series where it is assumed that there is indeed a change at an unknown time. Similarly, this procedure gives an estimate of the probability that the magnitude of the change has the value of the potential change in the mean.

Hubert method (Hubert et al., 1989) consists in dividing the series into $\mathrm{m}$ segments $(m>1)$ so that the average calculated on any segment is significantly different from the average of the neighbor segment (s). This method is suitable for detecting multiple changes in the mean.

\section{Results}

\section{Evolution of rainfall and flow over the whole Bouregreg watershed}

\section{Rainfall and hydrometric indices}

Over the whole of the Bouregreg basin, the period 1977-2007 is marked by two years of major deficits in 1994 and 2006 (Fig. 2). 
After the end of the 1970s, there was an increase not only in dry years but also in the magnitude of drought compared to the previous period. Apart from 1995 and 1996, all other years were dry. From 2002 appeared an alternation of positive and negative indices. Based on these indices expressed by the rainfall and hydrometric data for the period 1977-2007, the precipitation trend follows those observed in flow but with values sometimes significantly different. Then, in 2005 and 2006, opposite values of the two indices are recorded. To estimate this difference, Figure 2B shows the variation between rainfall and hydrometric indices. Resulting positive variation is obtained from the beginning of the drought (1979) to the NAO event (1995/1996). Since 1996, the variation becomes negative, with a rainfall index higher than the hydrometric index. This result seems to be explained by variability of annual cumulation that appears related to the number of events rather than to the amount of rainfall by rainy event (Lawin et al., 2011). At the level of the Bouregreg watershed, the number of rainy days per year varies from 60 to 75 between the mountains and the ocean and from 75 to 100 on the mountains. This can be also due to a durable impact of the drought on groundwater reserves which are much lower after ten years of drought, and the 1996 wet year is not sufficient to recover the previous groundwater level. Eventually, as it was not possible to get up to date data for all rivers, the time series ends in 2007, and it thus not possible to show if the wetter years recorded starting in 2008 have a positive impact on the discharges, as it seems observed from some other studies (Mahe et al., 2014).

\section{Monthly regime before and after the rupture (1979)}

Analysis and interpretation of the statistical tests revealed that for annual rainfall in the whole basin (Tab. 1), the rupture was detected in the years 1994 and 1997. This is related to a decrease in rainfall. However, some ruptures and trends can be observed at the end of the 1970s or at the beginning of the 1980s reflecting probably a change that would be more apparent at the scale of rainy event.

The monthly rainfall evolution over the two periods before and after the rupture (Fig. 3) shows a significant decrease between December and February over the whole basin. Rainfall declined in the 1980s, except in March. Rainfall totals evolved during the "great" rainy season November-December, while the "small" rainy season from March to April has almost disappeared, and a relative maximum appears in September-October.

To estimate the variation before and after 1979, the percentage of monthly rainfall is computed. We deduced a significant decrease of $14.3 \%$, from a total rainfall of 534 to $458 \mathrm{~mm}$, while in February there is an increase of $49 \%$, which made it difficult to be explained without investigating the evolution including many climatic parameters. The period of calculation of the flow before the drought is different from that of the rains, because the available data are longer (average of 4 stations of long duration), but the result is the same as including all stations over short period, with flow in February

Table 1. Observed ruptures by the statistical methods of Khronostat for rainfall and flow time series on the Bouregreg catchment, since 1977 to 2007. (NR = No rupture)

\begin{tabular}{|l|c|c|c|c|c|c|c|c|}
\hline \multirow{2}{*}{ Variable } & \multirow{2}{*}{ Period } & Pettitt & $\begin{array}{c}\text { Lee \& } \\
\text { Heghinian }\end{array}$ & Hubert & \multirow{2}{*}{ Buishand } & \multicolumn{3}{|c|}{ Probability of rupture } \\
\cline { 7 - 9 } & & & & & low & intermediate & strong \\
\hline Rainfall & $1977-2007$ & 1997 & 1997 & 1994 & NR & - & 1997 & - \\
& & & & 1998 & & & & \\
Flow & $1977-2007$ & NR & 1979 & 1979 & 1979 & - & - & 1979 \\
\hline
\end{tabular}



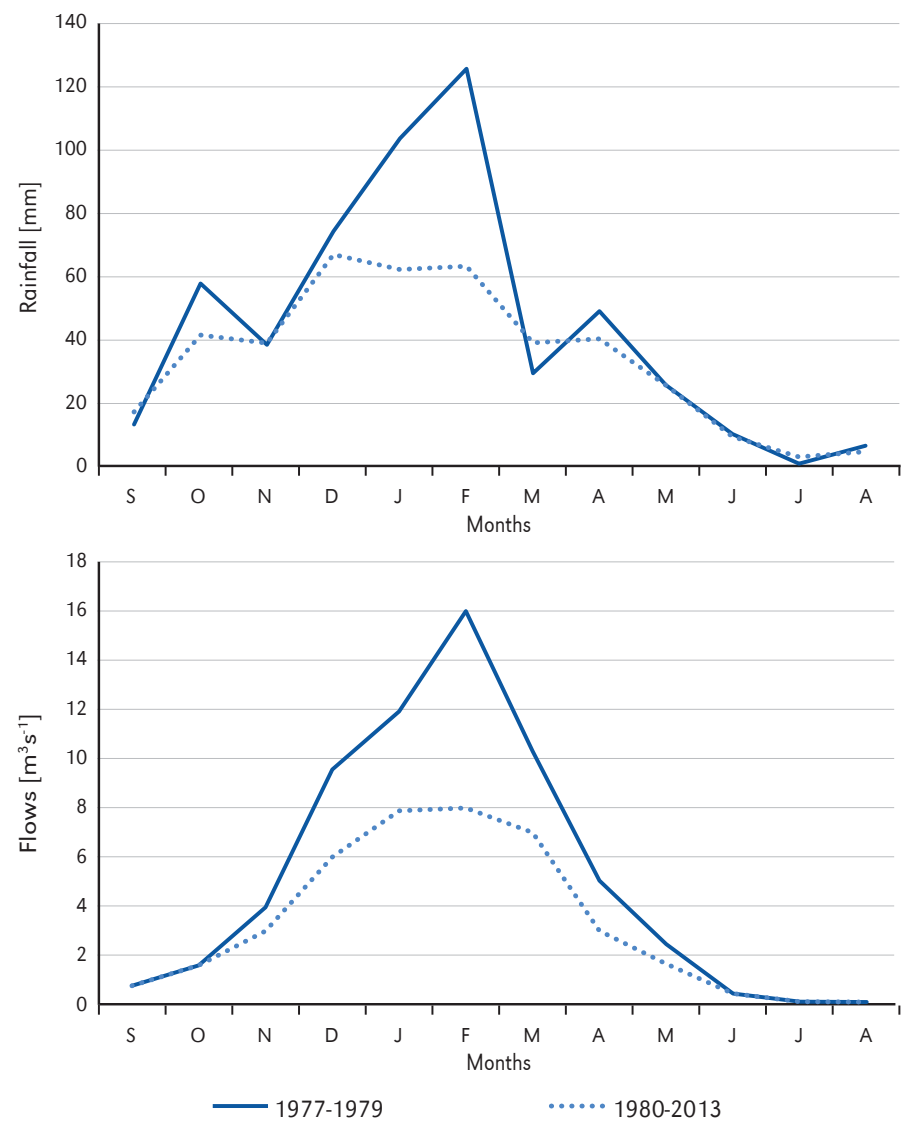

Figure 3. Evolution of the rainfall and flow monthly in the Bouregreg basin, since 1977 to 1979 and from 1980 to 2013 from September to August

and March higher over the short period 19771979. The monthly difference in flow between the two periods is close to $41 \%$.

\section{Regional study of rainfall and flow}

To investigate the evolution of rainfall and flow in the Bouregreg watershed by considering local heterogeneities of the distribution of rain, we have subdivided the large basin of the Bouregreg into climatic regions to reassess the annual and monthly series by sub-region. This provided new information by clearly showing the spread of different signals and we deduced sub-regions most vulnerable to climate change. The average rainfall for each sub-basin is obtained from the Thiessen polygon method based on the Delaunay triangulation using the mediator method between two stations.

The layer of each sub-watershed is taken with that of the Thiessen polygons in order to obtain the polygons on the sub-watersheds. Processing of the remaining stations leads to the constitution of seven polygons and thus of seven sub-watersheds basins (Fig. 1). We therefore identified seven sub-basins at different spatial scales in the Bouregreg watershed: Ezziar, Lalla Chafia, Tsalat, Ras Fathia, Haboub, Ain Loudah and Chref.

\section{Spatio-temporal variable rupture}

Statistical tests in the sub-basin index series are shown in Table 2. The establishment 
of the sub-regions is constrained by the number of stations used, their spatial distribution, and the duration of the series. However, there were ruptures in the 1970s in January 1977 and February 1979, as well as late ruptures in April 1997 at Chref, and in September 2007, November-October 2009 and July 2012 at the Ezziar and Lalla Chafia subbasin (Tab. 2). As for flow, it appears, through Table 3, a spatio-temporal variability of rupture dates at the Bouregreg scale. The probable ruptures are observed both in the rainy season and dry season. The tests show evidence for a period of negative rupture particularly at the end of the 79's. The rainfall series and to a lesser extent the flow series show very significant positive ruptures for almost all the stations at the end of the 2000s. However, January - February rainfall series and to a lesser extent by May, the rainfall

rebound due to a few successive years of best annual accumulation in the late 2000s did not change the long-term trend in JanuaryFebruary (Fig. 3). A direct impact on flow from December to February, is marked by the

Table 2. Rupture in the monthly rainfall time series of the Bouregreg sub-basins

\begin{tabular}{|l|r|r|r|r|r|r|r|r|r|r|r|r|r|}
\hline \multicolumn{1}{|c|}{ Sub-basins } & S & O & N & D & J & F & M & A & M & J & J & A & Total \\
\hline Ezziar & \multicolumn{1}{c|}{07} & 09 & 09 & 10 & 77 & 79 & 12 & 97 & 84 & & 12 & & \\
Lalla Chafia & 07 & 07 & 09 & 10 & 77 & 79 & 12 & 97 & 84 & 98 & 12 & & \\
Tsalat & 99 & 09 & 09 & 10 & 77 & 79 & 12 & 97 & 84 & 98 & 12 & 12 & \\
Ras Fathia & 11 & 09 & 09 & 94 & 78 & 78 & 12 & & 12 & & 12 & 12 & \\
Haboub & 11 & 09 & 09 & 94 & 77 & 79 & 12 & 97 & 85 & 98 & 12 & 12 & \\
Ain Loudah & 00 & 09 & 09 & 10 & 79 & 96 & 12 & 97 & & 98 & & & \\
Chref & 12 & 09 & 09 & 10 & & 94 & 96 & 97 & & 98 & & 99 & \\
Number of ruptures during 1970s & 0 & 0 & 0 & 0 & 6 & 5 & 0 & 0 & 0 & 0 & 0 & 0 & 11 \\
Number of ruptures during 1980s & 0 & 0 & 0 & 0 & 0 & 0 & 0 & 0 & 4 & 0 & 0 & 0 & 4 \\
Number of ruptures during 1990s & 1 & 0 & 0 & 2 & 0 & 2 & 1 & 6 & 0 & 5 & 0 & 1 & 18 \\
Number of ruptures after 1990s & 6 & 7 & 7 & 5 & 0 & 0 & 6 & 0 & 1 & 0 & 5 & 3 & 40 \\
\hline
\end{tabular}

Table 3. Rupture of monthly flow of the Bouregreg sub-basins

\begin{tabular}{|l|r|r|r|r|r|r|r|r|r|r|r|r|r|}
\hline \multicolumn{1}{|c|}{ Stations } & S & O & N & D & J & F & M & A & M & J & J & A & Total \\
\hline Ezziar & 96 & & 01 & & 77 & 79 & 80 & 03 & 04 & 79 & 79 & & \\
Lalla Chafia & & 78 & 01 & 94 & 78 & & 79 & 07 & 07 & & & & \\
Tsalat & 96 & & & & 78 & 79 & & 06 & & & & \\
Ras Fathia & & 04 & & 79 & 79 & 80 & 04 & 04 & & & & \\
Haboub & & & & & & 78 & 06 & & & & & & \\
Ain Loudah & & & 01 & & & 78 & & & & & \\
Chref & & 1 & 0 & 0 & 3 & 6 & 2 & 0 & 0 & 1 & 1 & 0 & 14 \\
Number of ruptures during 1970s & 0 & 1 & 0 & & & \\
Number of ruptures during 1980s & 0 & 0 & 0 & 0 & 0 & 0 & 2 & 0 & 0 & 0 & 0 & 0 & 2 \\
Number of ruptures during 1990s & 2 & 0 & 0 & 1 & 0 & 0 & 0 & 0 & 0 & 0 & 0 & 0 & 3 \\
Number of ruptures after 1990s & 0 & 2 & 5 & 0 & 0 & 0 & 1 & 3 & 5 & 0 & 0 & 0 & 16 \\
\hline
\end{tabular}


rupture in late 1970s. However, since the aquifers recharge the most during months of December to February we can expect a still marked impact on groundwater due to longterm trend decrease of rains during winter.

\section{Rainfall evolution}

Due to its geographical setting, Bouregreg watershed basin is under influence of the Atlantic and Mediterranean in addition to the relief effect. These features influence its climate on a global scale. We then investigate the contribution of climate change in the evolution of rainfall for each sub-basin. Figure 4 shows that the seven sub-basins present similar variation in rainfall distribution with a combination of positive and negative trends. The precipitations usually fluctuate between $162 \mathrm{~mm}$ and $1104 \mathrm{~mm}$. Some amplitudes are significantly different, with a much higher peak in the Tsalat sub-basin in 1996. This sub-basin is located near the town of Oulmes on the western mountains of the basin, which probably induces a specific variability of rainfall in this zone where the average rainfall at Oulmes station is of about 760 mm (Mahe et al., 2012; Tra Bi, 2013). However, the lowest height was recorded in 2001 in Ain Loudah located on the Korifla river which is coming from south, and is the driest
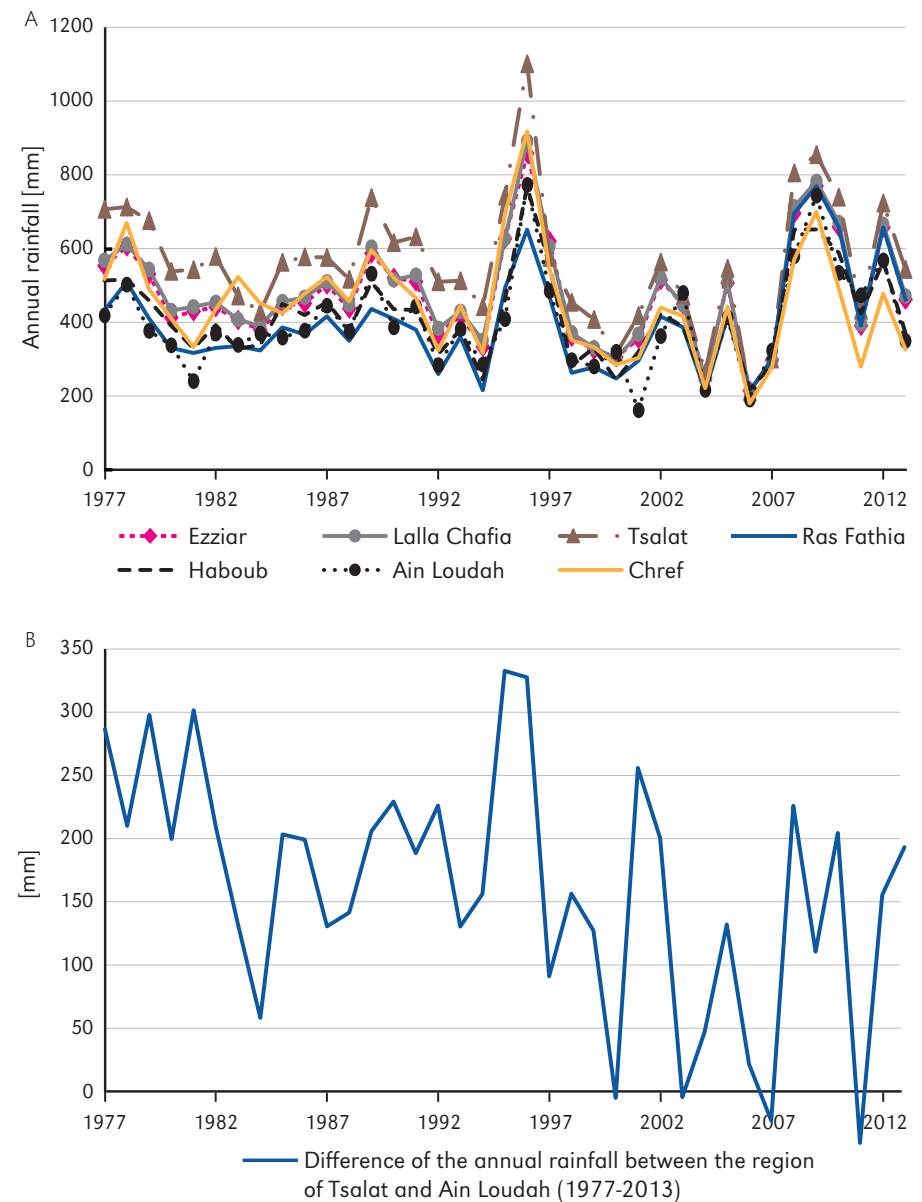

Figure 4. (A) Evolution of the annual rainfall on the Bouregreg sub-basins from 1977 to 2013; (B) Difference of the annual rainfall between the region of Tsalat and Ain Loudah (1977-2013) 
of all the Bouregreg. In 2006, we noticed a clearly increase in annual average values. The sub-basins have similar rainfall except two sub-regions: Tsalat and Ain Loudah. Rainfall from Tsalat is 40\% higher than that of Ain Loudah due to their geographical setting. We noticed also a decreasing difference between the two regions over the entire period. Tsalat sub-region which shows a significant downward trend compared to the Ain Loudah where it tends to lose less rain (Fig. 4B). The loss of about $100 \mathrm{~mm}$ per year since the end of $90 \mathrm{~s}$ on the high basin that is the rainiest region of the basin, compared to lower regions, does not augur positive trend for the next decades. While this trend is confirmed it will involve a sustainable decrease in water supply at the SMBA dam from Bouregreg river.

\section{Evolution of flow}

Figure 5 presents the annual flow available on long chronicles from 1977 to 2007 at seven stations: Tsalat, Ezziar, Ras Fathia, Ain Loudah, Lalla Chafia, Haboub and Sidi Jabeur. Since 1980-1982, annual discharges have been lower than during the 1970s which worsens drought, and greatly influenced hydrology during the same period. At all the stations of the watershed, a peak in 1996 is observed. Strong variation is observed between stations (Fig. 5). The flow at the stations (Ezziar, Ras Fathia, Haboub, Lalla Chafia and Sidi Jabeur) is regularly largely higher compared to the flow rate recorded at Ain Loudah and Chref stations. These last stations, located on the Oued Grou and Korifla basin, show significant variation even though they both are of low flow amplitude.

Previous studies highlighted net changes in annual flow that generally result in an increased flow in 1996, when it seems interesting to compare the difference before and after this date to follow the monthly evolution of the series and seasonal behavior at each station. Figure 6 shows the monthly flow increases from September to a peak in February, with a very significant decrease observed during the dry season which coincides with
June-August period. Haboub and Sidi Jaber, Ezziar, Ras Fathia stations show high scale of monthly flows compared to Chref, Tsalat, Ain Loudah stations. Local conditions may explain these important sub-regional variations. However, global trends of higher flow on all stations is observed from September to December and even January, and then systematically lower flow from January-February after 1996. This corresponds well to the average decline rains observed throughout the basin since the last decades. The very low flow rates at three stations indicate a very low underground reserve and correlatively a very weak recharge.

\section{Discussion}

Analysis and interpretation of the statistical tests revealed that for annual rainfall in the whole basin, the rupture was detected in the years 1994 and 1997. This is related to a decrease in rainfall. However, some ruptures and trends can be observed at the end of the 1970s or at the beginning of the 1980s reflecting probably a change that would be more evident at the scale of the rainy event. These results are in agreement with studies that investigated the evolution of rains in Africa showing the fastest warming periods during the twentieth century that are observed from the 1910 to 1930 s and after 1979 (Klaus, 2002). This also agreed with studies showing a decrease in rainfall in Morocco since the 1960s (Driouech, 2006; DMN, 2007), and significantly since the late 70's / early 80's (Agoumi \& Debbarh, 2006; Knippertz et al., 2003). This evolution of hydrological regime is reported by Singla et al. (2010) who included the rains in 1979. At the end of 1970s, there was a slight decrease in rainfall and in all sub-basins, which also noted a decrease in flow (monthly and annual flow) in Morocco since the end of the 1970s / early 1980s. We therefore assume that the decrease in flow is due to an overall decrease in precipitation over watershed. Similar trends are also observed by Khomsi et al. (2016) in the Tensift watershed and Ouahidy and Choukri 

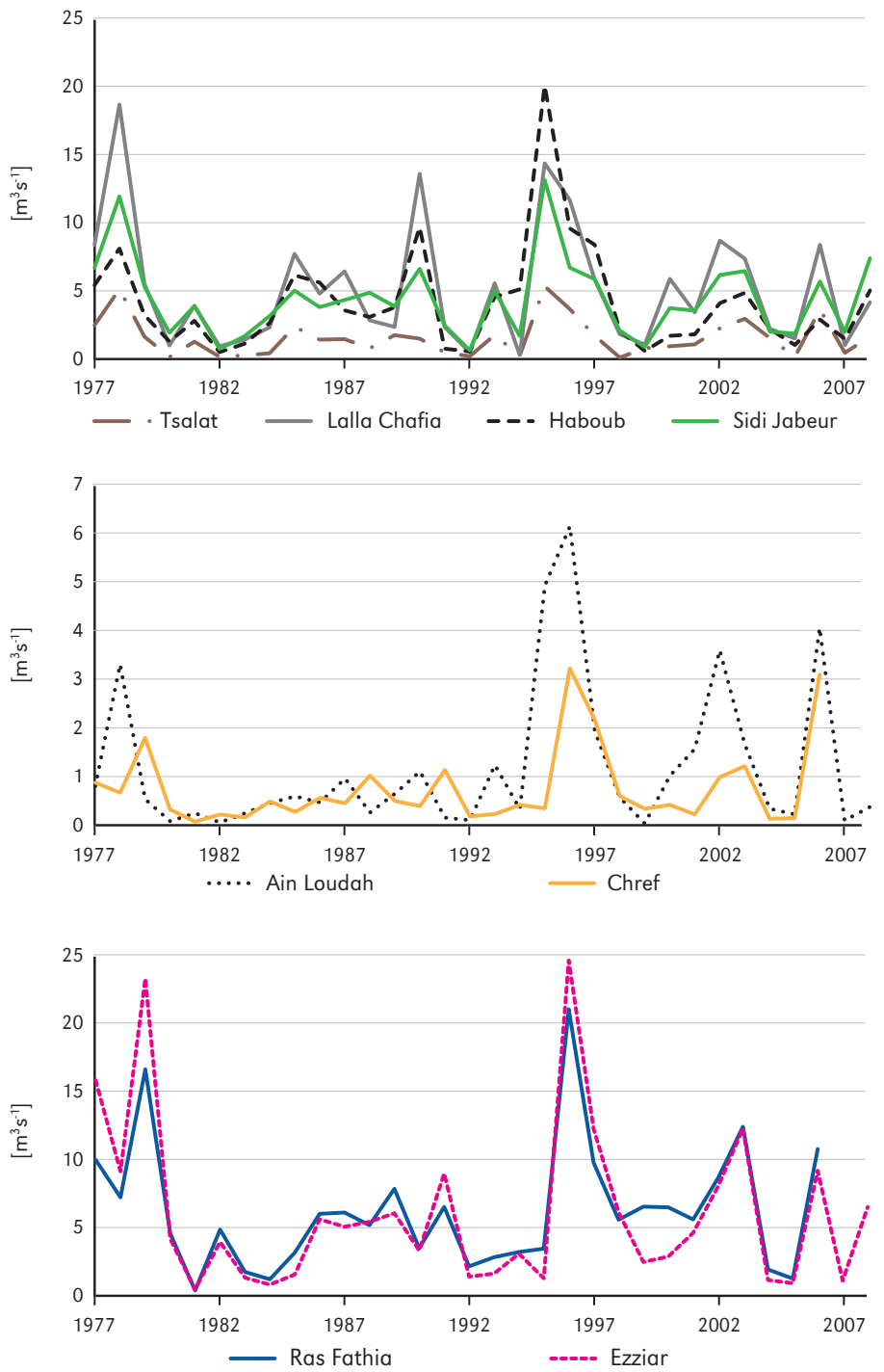

Figure 5. Evolution of the annual flow on the Bouregreg sub-basins from 1977 to $2007\left(\mathrm{~m}^{3} \mathrm{~s}^{-1}\right)$

(2018) in Rheraya watershed, located in the Hight Atlas of Marrakech (Morocco). Also, we noticed a peak in 1996, a year of heavy rain corresponding to the maximum flood period recorded for all the stations, which is consistent with the results of Khomsi et al. (2012). The year 1996 was of strong NAO anomaly favorable to rainfall in Morocco. According to Khomsi et al. (2016), the northern and southern regions of Bouregreg watershed are impacted differently by largescale atmospheric circulation and may respond in different ways to recent global warming. This response depends on the season studied and the considered region characteristics. At monthly time scale, the rainfall time-series present a statistically significant ruptures at the end of the 1970s. January and February rainfall amounts are the most affected by the reduction of rainfall 

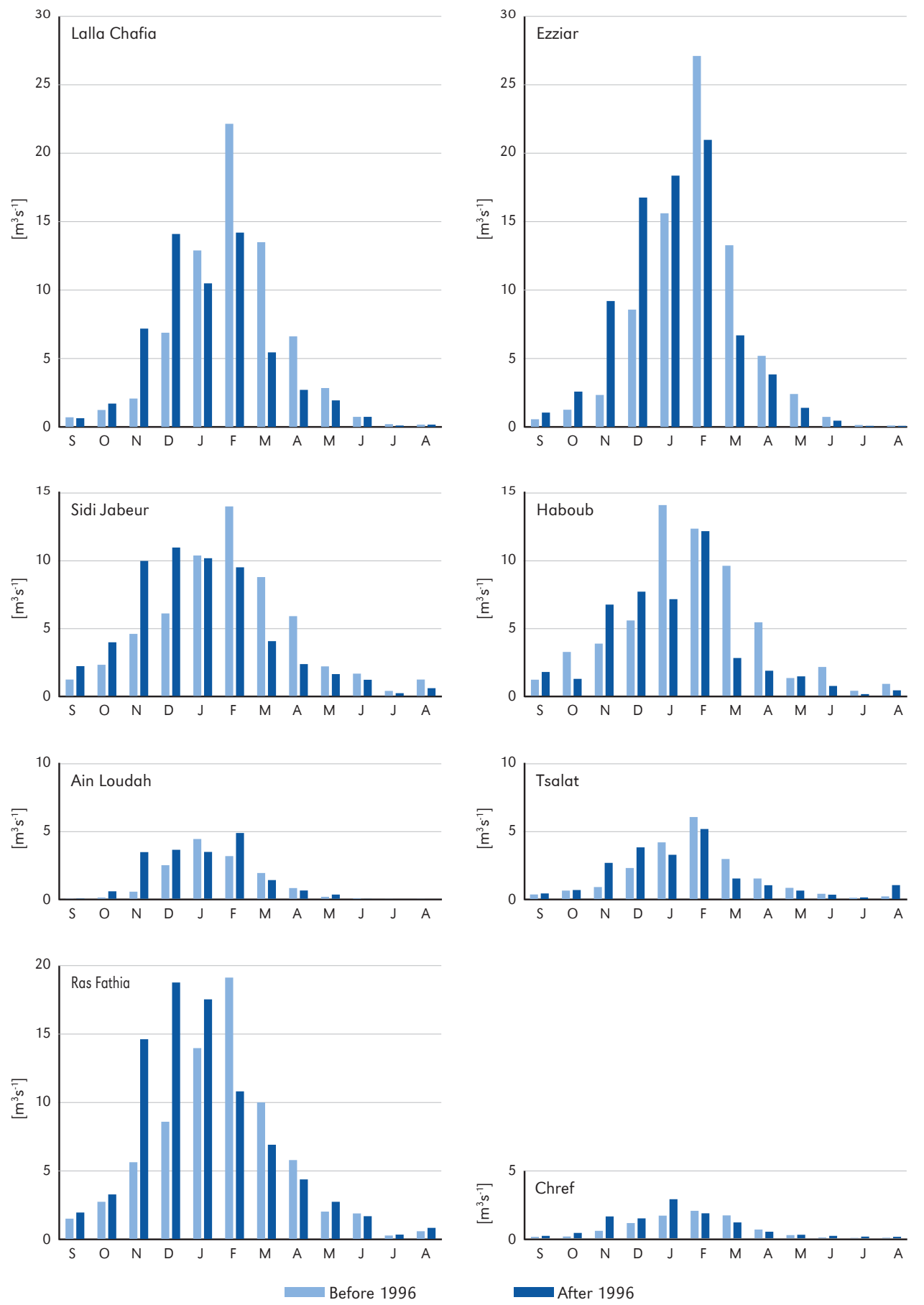

Figure 6. Evolution of the monthly flow for each station before and after 1996 for the period 1977-2007 $\left(\mathrm{m}^{3} \mathrm{~s}^{-1}\right)$ 
since the drought started end of the 1970's, inducing a reduction of flows at all hydrological stations mainly since 1979. Autumn and spring rainfall seem much less affected by the rainfall decrease, but show a positive change since around 2009 in October and November, but also during September and December around 2010 and March in 2012. Since then, rainfall has significantly increased all over the basin, but the runoff time series are too short to assess the impact of this rainfall recent increase on river flows. Lateral variation in monthly flow observed between stations of the basin shows evidence for local conditions that appears essential in investigating the hydrodynamic regime of a watershed. The difference observed between flow stations can be explained by the greater denudation of surface conditions in the Grou river, located farther south and drier than the basin of the Bouregreg river, and therefore is probably susceptible to higher flow from the beginning of the rainy season. The Ezziar and Ras Fathia stations exhibit identical behavior and particular year-to-year variability due to their proximity to the coastal zone, where water inflow is closely related to precipitation, which is around $400 \mathrm{~mm}$ and more important during floods. The Tsalat, Sidi Jabeur, Haboub and Lalla Chafia stations located in the Bouregreg and Grou rivers show important results related to topography. As the most watered regions are located in the high mountain basin, characterized by marked cashing of its valleys, by peaks and high plateaus which cross the north of the area, they concentrate the most important rainfall towards the dam by two main rivers, the Bouregreg and Grou. Lalla Chafia zone is located in alluvial depressions like the water table of Tanoubert, near Mâaziz city, in a wide band crossed by the Oued Tanoubert, tributary of Bouregreg and main source during floods. The results obtained from regional study of rainfall in Bouregreg, show that the sub-regions of Bouregreg watershed react differently to warming. This is related to the characteristics of each sub-region with a specific influence from relief and continental setting. These results are in agreement with the results found by Sebbar et al., 2017, who confirms that the north-western region of Morocco is characterized by high climatic variability, the climate there is influenced by the oceanity and altitude of watersheds.

\section{Conclusion}

Statistical methods of rupture detection showed that the major rupture period is during the second half of the 1970s and the beginning of the 1980s. Since that date the hydroclimatic variability exhibited an alternation of wet and dry periods with respect to the evolution of the rains and flow. Consequently, the hydrological regime of the basin is directly influenced by the precipitation regime. Thus, it can be noted that despite some bursts of relative abundance, the water flow of the Bouregreg watershed has steadily deteriorated. This persistent downward trend should be emphasized as it shows a lasting degradation of the hydrological system despite a fairly significant return to better precipitation conditions. We assume that the decrease in flow is mainly due to the decrease in rainfall in the Bouregreg watershed, and not to a major decline in groundwater resources. In order to identify the origin of the hydrological variability in the Bouregreg watershed, the Thiessen polygon method allowed to better investigate the climatic evolutions in the study area and to consider the contribution of each sub-region to the hydrological change. The findings of this study highlight strong variations between stations as the northern and southern sub-region of Bouregreg are influenced by continental setting and relief. Thus, there are isolated regions of plains, plateaus and mountains and high mountains, relatively close to or distant from the Atlantic and Mediterranean coasts.

\section{Acknowledgements}

This work is part of the Toubkal project No. TBK / 15 / CASBA (Anthropic and environmental characteristics of the erosion of the slopes of the Sidi Mohammed Ben Abdellah 
dam) carried out jointly by the Geophysics and Natural Hazards Laboratory of the Scientific Institute, Bouregreg and Chaouia Watershed Agency (ABHBC), and Montpellier HydroSciences Laboratory. Anonymous reviewers are thanked for their comments and suggestions.
Editors' note:

Unless otherwise stated, the sources of tables and figures are the authors', on the basis of their own research.

\section{References}

Agoumi, A., Debbarh, A. (2006). Ressource en eau et bassins versants du Maroc: 50 ans de développement (1955-2000). Retrieved from https://www.oieau.org/eaudoc/system/files/documents/41/206253/206253_doc.pdf

Beaudet, G. (1969). Le plateau central marocain et ses bordures: étude géomorphologique. Rabat: Imprimeries françaises et marocaines.

Bargaoui, Z., Tramblay, Y., Lawin, E.A., Servat, E. (2014). Seasonal precipitation variability in regional climate simulations over Northern basins of Tunisia. International Journal of Climatology, 34, 1, 235248. https://doi.org/10.1002/joc.3683

Boyer, J.F., Dieulin, C., Rouché, N., Crès, A., Servat, E., Paturel, J.E., Mahé, G. (2006). SIEREM: an environmental information system for water resources. IAHS Publications, 308, 19-25.

Buishand, T.A. (1984). Tests of detecting a shift in the mean of hydrological time series. Journal of Hydrology, 37(1-2), 51-69. https://doi.org/10.1016/0022-1694(84)90032-5

Dieulin, C., Boyer, J.F., Ardoin-Bardin, S., Dezetter, A. (2006). The contribution of GIS to hydrological modeling. IAHS Publications, 308, 68-74.

Dieulin, C., Mahe, G., Paturel, J.E., Ejjiyar, S., Tramblay, Y., Rouche, N., El Mansouri, B. (2019). A new 60-year 1940-199 monthly gridded rainfall data set for Africa. Water, 11(2), 387. https://doi.org/10.3390/w11020387

DMN (Direction de la Météorologie Nationale). (2007). Les changements climatiques au Maroc: Observations et projections. DMN, Secrétariat d'Etat auprès du Ministère de l'Energie, des Mines, de l'Eau et de l'Environnement, Chargé de l'Eau et de l'Environnement, Royaume du Maroc, Casablanca.

Driouech, F. (2006). Etude des indices de changements climatiques sur le Maroc : températures et précipitations. Infomet Maroc Meteo, 26, 33-38.

Driouech, F., Déqué, M., Sanchez-Gomez, E. (2010a). Weather regimes Moroccan precipitation link in a regional climate change simulation. Global and Planetary Change, 72, 1-10. https://doi.org/10.1016/j.gloplacha.2010.03.004

Driouech, F., Mahé, G., Déqué, M., Dieulin, C., EL Heirech, T., Milan, M., Benabdelfadel, H., Rouché, N. (2010b). Evaluation d'impacts potentiels de changements climatiques sur l'hydrologie du bassin versant de la Moulouya au Maroc. IAHS Publications, 340, 561-567.

Hadour, A., Mahe, G., Meddi, M. (2020). Watershed based hydrological evolution under climate change effect: An example from North Western Algeria. Journal of Hydrology Regional Studies, 28. https://doi.org/10.1016/j.ejrh.2020.100671

Hallouz, F., Meddi, M., Mahe, G. (2013). Modification du régime hydroclimatique dans le bassin de l'Oued Mina (nord-ouest d'Algérie). Journal of Water Science, 26, 1, 33-38. https://doi.org/10.7202/1014917ar

Hallouz, F., Meddi, M., Mahe, G., Toumi, S., Ali Rahamni, S.E. (2018). Erosion, sedimentation and climate change on the Wadi Mina at the Sidi M'Hamed Ben Aouda dam, Algeria. Water, 10, 7, 895.

https://doi.org/10.3390/w10070895 
Hallouz, F., Meddi, M., Mahe, G., Alirahmani, S., Karahacane, H., Brahini, S. (2020). Analysis of meteorological drought sequences at various time scales in semi-arid climate: Case of the Cheliff watershed (Northwest of Algeria). https://doi.org/10.1007/s12517-020-5256-5

Hubert, P., Carbonnel, J.P., Chaouche, A. (1989). Segmentation des séries hydrométéorologiques. Application à des séries de précipitations et de débits de l'Afrique de l'Ouest. Journal of Hydrology, 110, 349-367. https://doi.org/10.1016/0022-1694(89)90197-2

Khomsi, K., Mahe, G., Sinan, M., Snousi, M. (2012). Evolution des évènements chauds rares et très rares dans les bassins versants du Tensift et du Bouregreg (Maroc) et identification des types de temps synoptiques associés. In P. Versace, E. Ferrari (Eds.), From prediction to prevention of hydrological risk in Mediterranean countries:4th international Workshop on Hydrological extremes Med-Friend group: Department of Soil Protection "V. Marone" University of Calabria, Cosenza (Italy) September 15-17, 20119 (pp. 169-182). Cosenza: EdiBios.

Khomsi, K., Mahe, G., Sinan, M., Snousi, M. (2013). Hydro-climatic variability in two Moroccan watersheds: A comparative analysis of temperature, rain and flow regimes. In E. Boegh, E. Blyth, D.M. Hannah, H. Hisdal, H. Kunstmann, B. Su, K.K. Yilmaz (Eds.), Climate and land surface changes in hydrology, Wallingford, Oxfordshire, U.K.: IAHS Press.

Khomsi, K. (2014). Variabilité hydro climatique dans les bassins versants du Bouregreg et du Tensift au Maroc: moyennes, extrêmes et projections climatiques. (Typescript). Rabat, Maroc: Université Mohamed V.

Khomsi, K., Mahe, G., Tramblay, Y., Sinan, M., Snoussi, M. (2016). Regional impacts of global change: Seasonal trends in extreme rainfall, runoff and temperature in two contrasted regions of Morocco. Natural Hazards \& Earth System Sciences, 16(5), 1079-1090. https://doi.org/ 10.5194/nhess-16-1079-2016

Khronostat. (1998). Logiciel de tests statistiques de ruptures dans des séries chronologiques. IRD, France. Retrieved from http://www.hydrosciences.fr

Klaus, T. (2002). Afrique Changements climatiques. Tendance des variations de températures mondiales au cours du XXème siècle. Vital Graphics, p.4.

Knippertz, P., Christoph, M., Speth, P. (2003). Long term precipitation variability in Morocco and the link to the large scale circulation in recent and future climates. Meteorology and Atmospheric Physics, 83, 67-88. https://doi.org/10.1007/s00703-002-0561-y

Kotti, F., Mahe, G., Habaieb, H., Dieulin, C., Calvez, R. (2016). Etude des pluies et des débits sur le bassin versant de la Medjerda, Tunisie. Bulletin de I'Institut Scientifique, 38, 19-28.

https://doi.org/10.7202/705038ar

Lahlou, A. (1986). Etude actualisée de l'envasement des barrages au Maroc. Sciences de l'Eau, 6(3), 337-356.

Lawin, A.E., Afouda, A., Lebel, T. (2011). Analyse de la variabilité du régime pluviométrique dans la région agricole d'Ina au Bénin. European Journal of Scientific Research, 50(3), 425-439.

Lee, A.F.S., Heghinian, S.M. (1977). A shift of the mean level in a sequence of independent normal random variables, a Bayesian approach. Technometrics, 19, 503-506.https://doi.org/10.2307/1267892

Mahé, G., Delclaux, F., Crespy, A. (1994). Élaboration d'une chaine de traitement pluviométrique et application au calcul automatique de lames précipitées (bassin versant de l'Ogooué au Gabon). Hydrologie continentale, 9(2), 169-180.

Mahé, G., Emran, A., Brou, Y.T., Tra Bi, Z.A. (2012). Impact de la variabilité climatique sur l'état de surface du bassin versant du Bouregreg (Maroc). European Journal of Scientific Research, 84(3), 417-425.

Mahé, G., Aderghal, M., Alkarkouri, J., Benabdelfadel, H., Bensafia, D., Brou, ... Zerouali, A. (2013). Etude de l'évolution de l'occupation du sol sur deux grands bassins d'Algérie et du Maroc, et relation avec la sédimentation dans les barrages. In A. Schumann (Ed.), Considering hydrological change in reservoir planning and management. Wallingford, Oxfordshire, U.K.: IAHS Press

Mahé, G., Benabdelfadel, H., Dieulin, C., Elbaraka, M., Ezzaouini, M., Khomsi, K., ... Zerouali, A. (2014). Evolution des débits liquides et solides du Bouregreg. In A. Laouina, G. Mahe (Eds.), Gestion durable des terres. Proceedings de la réunion multi-acteurs sur le bassin du Bouregreg. CERGéo, Faculté des 
Lettres et Sciences Humaines, Université Mohammed V-Agdal, Rabat, 28 mai 2013. Rabat, Maroc: ARGDT.

Marghich, A. (2004). Le bassin versant de Bouregreg (Maroc Central): Etudes hydrologique, hydrogéologique et hydrochimie des eaux. (Typescript). Université Sidi Mohammed Ben Abdellah-Faculté des sciences Dhar Lmahraz.

Ouahidy, A., Choukri, M. (2018). Etude hydro-pluviométrique et estimation des débits de pointe du bassin versant de la Rheraya (Maroc). (Typescript). Faculté des Sciences et Technique de Marrakech, Morocco.

Pettitt, A.N. (1979). A non parametric approach to the change point problem. Journal of the Royal Statistical Society: Series C (Applied Statistics), 28(2), 126-135. https://doi.org/10.2307/2346729

Rivoire, P., Tramblay, Y., Neppel, L., Hertig, E., Vicente-Serrano, S.M. (2019). Impact of the dry-day definition on Mediterranean extreme dry-spell analysis. Natural Hazards and Earth System Sciences, 19(8), 1629-1638. https://doi.org/10.5194/nhess-19-1629-2019

Rouché, N., Mahé, G., Ardoin-Bardin, S., Brissaud, B., Boyer, J.F., Crès, A., Dieulin, C., Bardin, G., Commelard, G., Paturel, J.E., Dezetter, A., Servat, E. (2010). Constitution d'une grille de pluies mensuelles pour I'Afrique, période 1900-2000. Sécheresse 21, 4, 336-338. https://doi.org/10.1684/sec.2010.0269

Sebbar, A., Badri,W., Fougrach,H., Hsaine, M., Saloui, M. (2011). Étude de variabilité du régime pluviométrique au Maroc septentrional (1935-2004). Science et changements planétaires/Sécheresse, 22(3), 139-148.

Sebbar, A., Hsaine, M., Fougrach, H., Hama, S., Ajeddou, M., Badri, W. (2017). Etude des variations climatiques à la region Nord-Ouest du Maroc, débits de projet "bassin d'Oued Beht". XXXème colloque de l'Association Internationale de Climatologie, Sfax 03-06 juillet 2017.

Singla, S. (2009). Impact du changement climatique global sur les régimes hydroclimatiques au Maroc: tendances, ruptures et effets anthropiques sur les écoulements. (Typescript). Montpellier: Université de Montpellier 2.

Singla, S., Mahé, G., Dieulin, C., Driouech, F., Milano, M., El Guelai, F.Z., Ardoin-Bardin, S. (2010). Evolution des relations pluie-débit sur des bassins versants du Maroc. Global change: Facing risks and threats to water resources (Proceedings of the Sixth World FRIEND Conference, Fez, Morocco, October 2010). IAHS Publications, 340, 679-687.

Taibi, S., Meddi, M., Mahe, G., Assani, A. (2017). Relationships between atmospheric circulation indices and rainfall in Northern Algeria and comparison of observed and RCM-generated rainfall. Theoretical and Applied Climatology, 127(1-2), 241-257. https://doi.org/10.1007/s00704-015-1626-4

Taibi, S., Meddi, M., Mahe, G. (2019). Seasonal rainfall variability in the southern Mediterranean border: Observations, regional model simulations and future climate projections. Atmósfera, 32(1), 39-54. https://doi.org/10.20937/atm.2019.32.01.04

Tra Bi, Z.A. (2013). Etude de l'impact des activités anthropiques et de la variabilité climatique sur la végétation et les usages des sols, par utilisation de la télédétection et des statistiques agricoles, sur le bassin versant du Bouregreg (Maroc). (Typescript). Abidjan, Côte d'Ivoire: Université Félix Houphouët Boigny.

Tramblay, Y., Badi, W., Driouech, F., El Adlouni, S., Neppel, L., Servat, E. (2012). Climate change impacts on extreme precipitation in Morocco. Global Planet. Change, 82-83, 104-114.

https://doi.org/10.1016/j.gloplacha.2011.12.002

Tramblay, Y., Feki, H., Quintana-Segui, P., Guijarro, J.A. (2019). The SAFRAN daily gridded precipitation product in Tunisia (1979-2015). International Journal of Climatology, 39(15), 5830-5838. https://doi.org/10.1002/joc.6181

Tsiourtis, S. (2001). Drought management plans for the Mediterranean region. Report of the Water Engineer Water Development Department, Nicosia, Cyprus.

Zamrane, Z., Turki, I., Laignel, B., Mahe, G., Laftouhi, N. (2016a). Characterization of the interannual variability of precipitation and streamflow in Tensift and Ksob basins (Morocco) and links with the NAO. Atmosphere, 7(6), 84. https://doi.org/10.3390/atmos7060084 
Zamrane, Z., Laftouhi, N.E., Mahe, G., Laignel, B. (2016b). Relationship between climate index (WMOI, SOI) and rainfall variability in Azib Soltane (Sebou basin Marocco). Journal of Environment and Earth Science. 6(2), 34-42.

Zkhiri, W., Tramblay, Y., Hanich, L., Berjamy, B. (2017). Regional flood frequency analysis in the High Atlas mountainous catchments of Morocco. Natural Hazards, 86(2), 953-967.

https://doi.org/10.1007/s11069-016-2723-0 